\title{
The Contribution of Missionaries to Shona Lexicography*
}

\author{
Advice Viriri, Department of African Languages and Culture, Midlands State \\ University, Gweru, Zimbabwe (adviriri2002@yahoo.co.uk)
}

\begin{abstract}
The article discusses the developments in Shona lexicography during the colonial era and the contribution made by the missionaries in general and Father M. Hannan in particular which later resulted in the on-going process of compiling monolingual dictionaries by the African Languages Research Institute (ALRI) (into which the ALLEX project has been transformed). The missionaries employed various methods that did not only signal the beginning of an economically exploitative relationship between "the West and the rest of us" but also had ancillary cultural consequences (Dathorne 1975: 3). Their motives towards the development of African literature in general and Zimbabwean lexicographic work in particular were primarily evangelical and not to further creative writing. This caused Father Hannan to experience problems not only in his translation of the Shona Bible but also in his Standard Shona Dictionary. Hannan is used as an example because his translation problems were typical of those experienced by all missionaries. Hannan's dictionary was a welcome new development using the orthography introduced in 1931 and revised in 1955. The aim of his dictionary was "to record Shona words in Standard Shona spelling" (Hannan 1959: ix). Hannan's dictionary has made a considerable contribution to standardising Shona orthography.
\end{abstract}

Keywords: LEXICOGRAPHY, MISSIONARY, COBUILD, SHONA DICTIONARY, MONOLINGUAL DICTIONARY, BILINGUAL DICTIONARY, CULTURE, TRANSLATION, STANDARD ORTHOGRAPHY, COLONIALISM, CULTURAL IMPERIALISM, SHONA PROVERBS, AFRICAN LANGUAGES RESEARCH INSTITUTE (ALRI), INFLUENCE.

Opsomming: Die bydrae van sendelinge tot die Sjonaleksikografie. Die artikel bespreek die ontwikkelinge in Sjonaleksikografie gedurende die koloniale tydperk en die bydrae gemaak deur die sendelinge in die algemeen en Vader M. Hannan in die besonder, wat later uitgeloop het op die voortgaande proses van die samestelling van eentalige woordeboeke deur die African Languages Research Institute (ALRI) (waarin die ALLEX-projek omskep is). Die sendelinge het verskillende metodes gebruik wat nie net die begin van 'n ekonomies uitbuitende verhouding tussen "the West and the rest of us" ingelui het nie, maar ook bykomende kulturele gevolge gehad het (Dathorne 1975: 3). Hul motiewe betreffende die ontwikkeling van Afrikaliteratuur in die algemeen en Zimbabwiese leksikografiese werk in die besonder was primêr evangeliserend en nie om skeppende skryfwerk te bevorder nie. Dit het veroorsaak dat Vader Hannan probleme ondervind het nie net by sy vertaling van die Shona Bible nie, maar ook in sy Standard Shona Dictionary. Hannan word gebruik as voorbeeld omdat sy vertaalprobleme tipies was van dié wat alle sende-

* This article is a revised version of a paper presented at the Seventh International Conference of the African Association for Lexicography, organised by the Dictionary Unit of South African English, Rhodes University, Grahamstown, Republic of South Africa, 8-10 July 2002.

Lexikos 14 (AFRILEX-reeks/series 14: 2004): 349-358 
linge ervaar het. Hannan se woordeboek was 'n welkome nuwe ontwikkeling wat die ortografie gebruik wat in 1931 ingevoer en in 1955 hersien is. Die doel van sy woordeboek was "to record Shona words in Standard Shona spelling" (Hannan 1959: ix). Hannan se woordeboek het 'n aansienlike bydrae gelewer tot die standaardisering van die Sjonaortografie.

Sleutelwoorde: LEKSIKOGRAFIE, SENDELING, COBUILD, SJONAWOORDEBOEK, EENTALIGE WOORDEBOEK, TWEETALIGE WOORDEBOEK, KULTUUR, VERTALING, STANDAARD ORTOGRAFIE, KOLONIALISME, KULTURELE IMPERIALISME, SJONASPREEKWOORDE, AFRICAN LANGUAGES RESEARCH INSTITUTE (ALRI), INVLOED

\section{Introduction}

Africa's colonial experience had far-reaching implications. Not only did it create disorientation, alienation and economic domination but it also paved the way for cultural invasion, where the imperialists were authors and actors in the process in which the colonised were the subjects. This cultural hegemony sought to serve the interests of imperialism and was a form of cultural domination. For cultural imperialism to succeed, the colonised were to be convinced of their inferiority and the unquestionable superiority of the invaders.

The development of orthographies ushered in an epoch of literary translation that marked the beginning of African literature. Missionaries were the pathfinders and wayfarers of a literary tradition in Zimbabwe. The missionaries' main aim was the development of a Shona writing system, later devised by Doke and from 1931 onwards promoted as "Union Shona" (Chimhundu 1992: 79). Their contribution towards the development of African literature, especially vernacular literature and lexicography cannot be overemphasised. A.M. Chirgwin, a missionary secretary visiting Rhodesia, observed (Chirgwin 1932: 327):

The books that are in greatest demand are Bibles, hymn-books and catechisms. These are regarded by the people as so clearly a part of the necessary apparatus of a Christian that they purchase them without demur. The Pilgrim's Progress enjoys a steady sale in almost every African vernacular into which it has been translated.

The missionaries' motives were primarily evangelical, the intention being to convert Africans and becoming "the shepherds while Africans were the sheep" (Chiwome 1996: 11). While this did not give impetus to creative writing, previously unwritten African languages were reduced to writing. Literacy and literature were introduced to enable the smooth spreading of the gospel while Shona beliefs were not considered a religion.

In order to exert their influence, these missionaries set up stations at geographically strategic positions in most Shona-speaking areas, graphically presented by Chimhundu (1992: 80) as follows: 


\begin{tabular}{|c|c|c|c|}
\hline Dialect & $\begin{array}{c}\text { Denomination } \\
\text { (Missionary Society) }\end{array}$ & $\begin{array}{c}\text { Mission(s)/Headquarters } \\
\text { (Year Established) }\end{array}$ & $\begin{array}{c}\text { Nearest Town } \\
\text { (New Name) }\end{array}$ \\
\hline Ndau & $\begin{array}{l}\text { American Board Mission } \\
\text { (American Methodist) }\end{array}$ & $\begin{array}{l}\text { Mount Selinda } \\
\text { Chikore } \\
(1893)\end{array}$ & $\begin{array}{l}\text { Chipinge } \\
\text { Melsetter } \\
\text { (Chimanimani) }\end{array}$ \\
\hline \multirow[t]{3}{*}{ Manyika } & 1. Anglican Church & $\begin{array}{l}\text { Penhalonga } \\
\text { (St Augustine's) } \\
(1898)\end{array}$ & $\begin{array}{l}\text { Umtali } \\
\text { (Mutare) }\end{array}$ \\
\hline & $\begin{array}{l}\text { 2. } \begin{array}{l}\text { Methodist Episcopal } \\
\text { (United Methodist) }\end{array} \\
\end{array}$ & $\begin{array}{l}\text { Old Umtali } \\
(1892)\end{array}$ & $\begin{array}{l}\text { Umtali } \\
\text { (Mutare) }\end{array}$ \\
\hline & $\begin{array}{l}\text { 3. Roman Catholic } \\
\text { Church }\end{array}$ & $\begin{array}{l}\text { Triashill } \\
(1896)\end{array}$ & Rusape \\
\hline \multirow[t]{2}{*}{ Zezuru } & $\begin{array}{l}\text { 1. Roman Catholic } \\
\text { Church }\end{array}$ & $\begin{array}{l}\text { Chishawasha } \\
\text { (1892) }\end{array}$ & $\begin{array}{l}\text { Salisbury } \\
\text { (Harare) }\end{array}$ \\
\hline & $\begin{array}{l}\text { 2. Methodist Church } \\
\text { (Wesleyan) }\end{array}$ & $\begin{array}{l}\text { Waddilove } \\
(1892) \\
\text { Epworth } \\
(1892)\end{array}$ & $\begin{array}{l}\text { Marandellas } \\
\text { (Marondera) } \\
\text { Salisbury } \\
\text { (Harare) }\end{array}$ \\
\hline Karanga & Dutch Reformed Church & $\begin{array}{l}\text { Morgenster } \\
(1891)\end{array}$ & $\begin{array}{l}\text { Fort Victoria } \\
\text { (Masvingo) }\end{array}$ \\
\hline $\begin{array}{l}\text { Kalanga (and } \\
\text { Ndebele) }\end{array}$ & $\begin{array}{l}\text { London Missionary } \\
\text { Society }\end{array}$ & $\begin{array}{l}\text { Inyati; Hope Fountain } \\
(1859 ; 1870)\end{array}$ & Bulawayo \\
\hline
\end{tabular}

As a result of missionaries settling at different mission stations, a variety of approaches to the making of dictionaries for use by the indigenous population were devised. These mission stations represented the different Shona dialects spoken in Zimbabwe, namely ChiZezuru, ChiNdau, ChiManyika and ChiKaranga. The ChiKorekore dialect was not represented in the writing panel because the missionaries shunned the swelteringly hot, tsetse fly and mosquito infested Zambezi valley where the Korekore people live.

\section{A Brief History of Bilingual Dictionaries in Zimbabwe}

According to George Fortune (1979: 42), a pioneer Bantu comparativist, W.H.I. Bleek, first made a list of Shona words entitled The Languages of Mosambique (1856) and surveyed the Sofala dialect along the Pungwe-Save rivers.

M.E. Weale wrote the first Matabele and Makalaka Vocabulary Intended for the Use of Prospectors and Farmers in Mashonaland (1903), representing Karanga. In 1894, Reverend A.M. Hartmann, a chaplain of the pioneer column, compiled The English-Mashona Dictionary in the Zezuru dialect. This was followed by W.A. Elliot who in 1897 published the Dictionary of the Tebele and Shona Languages. Elliot's work was "an attempt to present a written basis for the Shona language as a whole, from which the peculiarities of the different dialects may be observed".

H.E. Springer of Old Umtali published A Hand Book of Chikaranga (1905) and Father E. Beihler followed with his 1906 publication of the English-ChiSwina Dictionary with an Outline of ChiSwina Grammar. The subsequent editions 
that culminated in the third which received more attention, was entitled ChiSwina Grammar with English-ChiSwina Dictionary, and ChiSwina-English Vocabulary. The following edition substituted the term ChiSwina, possibly because it sounded derogatory, with ChiShona, hence the title adopted was MaShona or ChiSwina Vocabulary. Finally the fourth edition dropped the designation ChiSwina completely. After Beihler's first edition, A Dictionary with Notes of the Grammar of the Mashona Language Commonly Called ChiSwina that dealt with Manyika, was the next compilation by Father H. Buck at St Augustine's Mission, Penhalonga. A small English-Chikaranga Dictionary was produced in 1926.

In 1951, a first vocabulary of the Ndau dialect that came in use was entitled ChiNdau-English and English-ChiNdau Vocabulary, the compiler being anonymous. However, it is believed to be the Reverend G.A. Wilder's work. This same year, C.S. Louw published her Manual of the Chikaranga Language whose main objective was "to provide for the European student a gradual introduction to the grammar of this important branch of the group of African Native languages known as the Bantu family".

For Christianity to thrive, missionaries needed a mastery of the indigenous languages. It was therefore imperative to develop a writing system in Shona. Christianity was a significant force in African colonisation. It helped to reduce Africans to submission and eventually assisted European powers to take over African land. Various avenues of persuasion were explored to save Africans from their so-called pagan and heathen cultural practices. It is quite evident from this objective that the missionaries' main aim in compiling these dictionaries were to facilitate the translation of the Bible and other religious and educational material from English, and also to help Europeans in using Shona. Fortune (1979: 45) says "the perspective of all these works ... had been to assist foreigners to speak local forms of Shona".

Shona lexicography was supposed to play a social role in the standardisation of the Shona language. By standard Shona, Chimhundu (1992: 87) says, is meant: "developing a common system of writing or orthography (that is, spelling, word-division, and also punctuation) which, when implemented, allows people who speak different varieties of the same language to write in the same way, while still allowing for stylistic and other variation, as in the choice of vocabulary".

Apart from developing orthographies, missionaries also established and controlled schools. It was their great desire to propagate Christianity among what they considered African heathens who needed a thorough teaching. The aim was also to establish a literate class who could be functional in colonial administration and commerce. It was out of these schools that a new intelligentsia of first generation writers emerged.

What then, were the consequences of these developments on African literary expression in general and the Shona lexicographic development in particular? Oral art forms were inevitably undermined, though not obliterated, by 
the emergence of schooling and literacy. With the transition to a literary culture, the early African writers, being experienced in an oral culture, required a reorganisation of their entire aesthetic sensibilities.

The main institution that worked for a common orthography and lexicography among the Shona was the Southern Rhodesian Missionary Conference which was first held in 1903. The main purpose of this meeting was to secure a translation that could be used in all dialects of Mashonaland.

At the Missionary Conference held in 1906, the common version of the Bible and a common orthography were topical issues. In 1928, the Southern Rhodesian Government decided to support the use of African languages and the missionaries were encouraged, according to Fortune (1979: 46), to "put their heads together to get a common language suitable to the needs of the different Mashona tribes, so that larger and less expensive editions of higher class textbooks be printed".

For a language to develop into a standard language means serious efforts in lexicography. This explains why among Doke's 1931 recommendations was the unification of the orthographies and the vocabularies. The New Unified Orthographies for schools in 1932 and the Standard Shona for the country in 1955 led to the publication of the last series of dictionaries and vocabularies before Hannan's Standard Shona Dictionary, called A Vocabulary of the Dialects of Mashonaland in the New Orthography compiled by Reverend Bertram H. Barnes, CR.

In spite of this large amount of lexicographic work, the missionaries played a negative role in the development of African literature which should be examined in the tripartite relationship of education, colonial Christianity and African culture. Missionaries viewed African customs and morality as degraded by barbarism and superstition, so their aim was to remake Africans through the Gospel and education. This is why Chiwome (1996: 11) concedes: "Initially the church was fundamentalist, hierarchical, sectarian and authoritarian ... It did not tolerate Shona religion and customs."

Certainly, the church provided the social engineering necessary while schools provided the literacy and literary culture essential to a scripturally based faith. Thus the cultural policy of the mission schools was inimical to the African's cultivation of his traditional art. All Christian converts were expected to renounce their traditional practices. A missionary writer stationed at Zimbabwe's Gokomere Mission in 1949, Father Gruber, did not think that any African art existed in pre-colonial Rhodesia (Peet 1949).

\section{Problems of Bilingual Dictionaries}

Any speech community jealously guards the historical associations and institutions peculiar to itself through language. It is language as a cultural asset that is used by people for transmission of their knowledge systems and information. Differences in culture may result in one language using a concept on a higher 
level of abstraction than the other, thereby having a gradient between the two closest equivalences. For example, Hannan explains njuzu as a "water sprite" while sprite is a "fairy". In the Shona cultural context, people should, however, know that if a njuzu takes a person, relatives are not supposed to mourn if that person is to be returned alive. Also, on his/her return, he/she will be possessed with great magical powers, as is indicated in Chimhundu's dictionary. The cultural range in translation should have been considered.

Any serious attempt to define culture should include, according to Ngara (1991: 2), the following indices: the material culture, the aspect of social relations and communication, the ideological element and the aesthetic component of a group of people. The analysis of these indices in relation to Shona lexicography, in its organic unity, will show that culture is "the expression of a people's social activities in relation to their struggle with their environment, with the elements and with human forces that threaten their survival or their way of life".

With the view that the Shona language enables people's daily experiences to be conveyed fully and vividly, Father Hannan's "contribution towards the study of the Shona language and the development of its written literature" (Fortune 1979: 21), should not be underestimated.

Since any dictionary is considered a reference text generally associated with translation of lexical items, Father Hannan is to be evaluated as a lexicographer and translator through his Standard Shona Dictionary (1959). Being a bilingual dictionary, his "considerations regarding its relative usefulness to first and second-language speakers" were necessary during the colonial era.

Many people regard dictionaries as infallible authorities on language usage, which is not true. In Father Hannan's dictionary, the inconsistencies and inadequacies are created by "the complex language situation in the Shonaspeaking community" (Chimhundu 1979: 75). A dictionary should record and describe usage. Pinchuck (1977: 225) succinctly sums up the functions of a dictionary when he says:

Ideally a dictionary should be an instrument of semantic discrimination. It should enable the user to choose between words for a given application; and it should offer information about the position of a word within a series and its value within a lexical structure.

\section{Hannan's Dictionary as Example}

Being a bilingual dictionary, Hannan's Standard Shona Dictionary was and is quite useful and particularly important for its target users who were fellow foreigners learning Shona. In his effort to translate, Hannan was faced with the major problem of whether to find equivalents that are one-to-one correspondences or single words replacing word groups or compounds and the reverse, hence the creation of collocations or single words or word groups. His explanation of dare describes it as a "meeting place for the men of a village". Dare can 
refer to a court or, within a house complex, to the resting place of males where they can advise adolescent boys on how to contend with growing-up problems. The word can also mean a bell. Unfortunately, he had problems with recognising Shona homonyms.

Hannan's major weakness is that he furnishes standardised translations not corresponding with the full lexical ranges in the two languages and therefore ends up being incorrect because of the shifts of meaning in both languages. In an interview with Hannan a month before he died, Kumbirai (1979: 61) reported Hannan's comments on his difficulties in translating the New Testament into the Shona language:

The Shona people spoke many dialects and he had, therefore, to take cognizance of this fact in his translation; that about half of the translation was entirely by himself and might therefore be discounted by native Shona speakers as "Chibaba" (which can be freely interpreted as the "Shona spoken by missionaries); and that some missionaries who knew Greek, Hebrew and Aramaic maintained that some of his translation did not do justice to the original, and, therefore, did not measure up to the world's standard of translation (and for this reason some Catholic missionaries even preferred to use the Dutch Reformed Church (Morgenster) translation).

The fact that at one time Father Hannan wished he was a native speaker who could have rendered his translations more intelligible and meaningful (Kumbirai 1979: 62), clearly spells out his linguistic deficiencies particularly for a speaker of both the source and target languages.

Since Father Hannan was a foreign speaker of the Shona language, some of his translations do not give a rendition of the vocabulary as used in normal everyday speech and therefore are not comprehensible and contemporary. While he tried to capture Shona words that occur relatively frequently in daily usage, this have had great value for the recording of the vocabulary. The most common words often have little information value, though they are important functionally. Hannan's main aim to describe the lexical items are not prescriptive in practice. The Shona language is heterogeneous and the social situation in its usage is fluid.

Hannan's dictionary presents the Shona language as an inventory, a list of words unconnected to each other, instead of offering it as a structured and patterned system of words as used in practice (Pinchuck 1977: 225). As nonnative speaker of the Shona language Father Hannan encountered a multiplicity of problems. One controversial entry in his dictionary is the following: "Kipa: storekeeper Eng. Kipachitoro and Kipasitoro also occur". For Hannan to define Kipa only to mean a "storekeeper" is misleading. He gives examples without first giving a definition. Kipa, a loan word from English "keeper", means someone whose job is to look after a particular place, for example a storekeeper, goalkeeper, zookeeper, etc. Chimhundu's Duramazwi Guru ReChiShona rightly says that "Kipa is Muchengeti (i) Kipasitoro (ii) Gedhebhoi". Hannan's weak- 
ness in this regard shows the need for recognising the crucial role of context. Meaning therefore is a result of context and it is this context that disambiguates.

\section{Hannan's Major Weaknesses}

Father Hannan's Standard Shona Dictionary should have been both true to the cultural facts and be informative about Shona lexical details. He was supposed to give precise descriptions of meaning. For example, he defines zhumu as "big tuft of hair left on shaven head (esp. of boys)". While this is correct, it is incomplete. Even animals like bucks have tufts. Father Hannan gives examples of words found in proverbs but, showing his deficiency in the Shona language, he omitted one of the most interesting proverbial sayings, mhembwe rudzi inozvara mwana ane kazhumu which can be translated to mean "a duiker is one of a species, if it bears a child, it will have a tuft on his head". One of his major weaknesses is his inadequate research about the exact uses and meanings of words and expressions.

Hannan's dictionary therefore neglects the reinforcing of some of the Shona people's cultural values. A proverb is a mirror of a cultural context expressing the philosophy of life in society. It is, according to Dorson (1972: 21), "a living recitation delivered to a responsive audience for such cultural purposes as reinforcement of custom and taboo, release of aggressions through fantasy, pedagogical explanations of the cultural world, and application of pressure for conventional behavior". Chimhundu (1980) supports this by adding that proverbs contain the distilled wit and wisdom of past generations because they enjoy users' "traditional popular acceptance" (Doke 1947: 102, quoted by Chimhundu 1980: 41).

Hannan's explanation of zhumu does not contain an example sentence of its use as is the case of other words which form part of proverbs, making its treatment inconsistent with these. Hannan's formulations, apart from being confusing, do not faithfully reflect the facts of the natural language and introduces many distortions. Most of Hannan's explanations are incorporated into the "definition". They show the typical short-comings of traditional lexicography. Explanations about what words mean are written but "very little is said about how they are used" (Hanks 1987: 121).

Hannan is found wanting in his converting information from one language or language variety into another. For example, it is not enough to explain matakanana as: "Muddy water. Any badly done work." It specifically refers to a children's game as appears from Chimhundu's (1996: 261) definition:

Aya matambiro evana vadiki diki vachitevedzera zvinoitwa mudzimba nevakuru sezvakaita kubika, vachishandisa mavhu nemvura.

"It is children's play imitating what elders do in carrying out household chores like cooking but they would be using sand and water". 
Any dictionary should identify items in terms of what Gleason (1973: 3) calls the "structure of content", the system of interrelated meanings and values which is at the heart of a culture. Any translator is expected to be linguistically competent with a good background in the literature, culture and history of the language from which lexical items are translated.

Fortune (1979: 28) admittedly pointed out that Hannan's dictionary is "deficient in words used in the diction of traditional poetry".

No doubt many of these words are passing out of the speech of all but the oldest age grades, and this fact points to another aspect of the difficulty in determining what is a complete record. For with changes in culture the lexicon is proving unstable.

Father Hannan furthermore failed to translate some words into Shona or English which makes his definitions difficult and unfamiliar. For a Shona word like manyemba to be defined by its scientific name Smegma praeputtii is confusing to ordinary users and only understandable to a few learned people. In translating written or recorded material of a natural language, the aim is to reproduce as accurately as possible all grammatical and lexical features of the source language by equivalents in the target language. This is why Zgusta (1971: 257) in his principles of defining says:

The lexicographic definition (should) not contain words more difficult to understand than the explained word itself.

Through its many editions and printings Father Hannan's Standard Shona Dictionary, however, contributed greatly towards the general establishment of the standard Shona orthography.

\section{Conclusion}

The development of African and specifically Zimbabwean literature and lexicography shows that mission-mediated literature and lexicography faithfully reflects colonialism. With Christianity, its missions and presses were but loyal partners to the steady tightening of colonial power and the deepening subjugation of the blacks. Mission presses also did not allow the voice of black protest to be heard in their publications. However, these mission presses contributed towards the establishment of a writing and lexicographic tradition for Shona in Zimbabwe.

The lexicographic efforts of the missionaries in general, and that of Father Hannan in particular, have many weaknesses. Basically not meant for the studying of Shona for its own sake, these dictionaries were compiled by nonnative speakers of Shona who worked as individuals, unable to consult a wide range of native speakers for the exact uses and meanings of words and expressions. 
This early missionary lexicographic tradition later resulted in the on-going process of compiling monolingual dictionaries by the African Languages Research Institute (ALRI) (into which the ALLEX project has been transformed). Shona has now become a field of study in its own right as demonstrated by Chimhundu's dictionaries compiled electronically by a team of professional lexicographers with the help of a comprehensive database.

\section{References}

Chimhundu, H. 1979. Some Problems Relating to the Incorporation of Loanwords in the Lexicon. Zambezia 7(1): 75-91.

Chimhundu, H. 1980. Shumo, Tsumo and Socialisation. Zambezia 8(1): 37-51.

Chimhundu, H. 1990. Pragmatic Translation and Language Elaboration. Pongweni, A.J.C. and Thondlana (Eds.). 1990. Lasu Conference Proceedings 1987: 140-152. Harare: Lasu.

Chimhundu, H. 1992. Standard Shona: Myth and Reality. Crawhall, N.T. (Ed). 1992. Democratically Speaking: International Perspectives on Language Planning: 77-88. Cape Town: National Language Project.

Chimhundu, H. (Ed.). 1996. Duramazwi RechiShona. Harare: College Press.

Chimhundu, H. (Ed.). 2001. Duramazwi Guru RechiShona. Harare: College Press.

Chirgwin, A.M. 1932. Christian Literature in Africa. Africa 5: 323-337.

Chiwome, E.M. 1996. A Social History of the Shona Novel. Kadoma: Juta.

Dathorne, O.R. 1978. African Literature in the Twentieth Century. Minneapolis University: Minnesota Press.

Doke, C.M. 1931. Report on the Unification of the Shona Dialects. Hertford: Stephen Austin and Sons.

Doke, C.M. 1947. Bantu Wisdom-Lore. African Studies 6: 101-120.

Dorson, Richard M. 1972. Concepts of Folklore and Folklife Studies. Dorson, Richard M. (Ed.). 1972. Folklore and Folklife: An Introduction. Chicago/London: University of Chicago Press.

Fortune, G. 1979. Shona Lexicography. Zambezia 7(1): 21-47.

Gleason, D. 1973. An Introduction to Descriptive Linguistics. Essex: Longman.

Hanks, P. 1987. Definitions and Explanations. Sinclair, John M. (Ed.). 1987. Looking Up. An Account of the COBUILD Project in Lexical Computing and the Development of the Collins COBUILD English Language Dictionary: 115-136. London/Glasgow: Collins ELT.

Hannan, M. 1959. Standard Shona Dictionary. Harare: The College Press/The Literature Bureau.

Kumbirai, J.C. 1979. Shona Bible Translation: The Work of the Revd Michael Hannan, S.J. Zambezia 7(1): 61-74.

Ngara, E. 1991. Culture for Liberation and Social Transformation. Unpublished paper read at the Ministry of Education and Culture Seminar on Cultural Awareness, held at the Kadoma Ranch Motel, 15-17 May 1991.

Peet, S. 1949. Report of the Visit to the Range of Fort Victoria, Gutu Reserve 25-31 March 1949. Central Africa Film Unit File F 268 to 269. Harare: National Archives of Zimbabwe.

Pinchuck, I. 1977. Scientific and Technical Translation. London: André Deutsch.

Zgusta, L. 1971. Manual of Lexicography. Janua Linguarum. Series Maior 39. The Hague: Mouton. 